\title{
Property Enhancement of Aluminium Based MMCs with Various Reinforcements
}

\author{
Jessy Michla. J.R, Rajini. N
}

\begin{abstract}
Aluminium Matrix Composites are used in a wide variety of fields like Aerospace, Marine, Automotive industries, structural applications, etc. This review paper is concerned with the different Aluminium alloys with various reinforcements and studies the properties like strength, stiffness, hardness, wear rate and porosity. It mainly aimed at the evolution of Aluminium Matrix composites in the Aviation sector. The need for better performance, low cost and quite quality materials are upgraded by the latest MMCs and novel manufacturing processes. With the reinforcements like Silicon Carbide, Boron Carbide, Titanium Oxide, etc. improved the mechanical and tribological properties of MMCs. Likewise, the Fabrication Techniques such as Powder Metallurgy as well as stir casting improved the performance of MMCs.
\end{abstract}

Keywords: Metal Matrix Composites, Al based MMCs, Reinforcements, Fabrication Techniques, Mechanical Properties

\section{INTRODUCTION}

Aviation industry has a great challenge for researchers to sustain the atmospheric pressure, temperature, weight, etc. whereas composite materials overcome such difficulties in a high environment. Metals are one among the hardest materials that exist abundantly in nature, which could exhibit good mechanical and physical properties. Even then most of the metals are not used in their purest form, as they are brittle in nature. They are mixed with some other materials to form alloys. Alloys are a result of atomic bonding between the metals and other constituents of it. Alloying of metals increases its strength, melting point, hardness, ductility and other desired properties. However, alloys are too heavy so that it is overcome by Metal Matrix Composites (MMC). MMC's have high strength to weight ratio when compared to alloys and also exhibits better load bearing capacity. Metals gives excellent specific strength and stiffness, isotropic properties, ease of manufacturing to near net shape, and excellent thermal and electrical properties, and affordability, producing discontinuous MMCs suitable for a massive range of aerospace applications and also it provide high structural efficiency and isotropic properties of discontinuous MMCs with the required multi-axial loading when high loads are encountered.

Revised Manuscript Received on December 15, 2019.

* Correspondence Author

Jessy Michla J R, Mechanical Engineering, Kalasalingam Academy of Research and Education, Srivilliputhur, India.Email: jes.michla@gmail.com

*Rajini N, Mechanical Engineering, Kalasalingam Academy of Research and Education, Srivilliputhur, India.Email: rajiniklu@ gmail.com

\section{REINFORCEMENTS AND ITS CHANGE IN PROPERTIES}

Various Reinforcements of Aluminium like silicon carbide, alumina, graphite, fly ash, $\mathrm{ZrO}_{2}$ etc. are easily added and found to be cheap in an increasing requirement of aerospace applications. Al matrix composites reinforced with three reinforcement fibres namely $\mathrm{SiC}$ fibres, optical fibres and shape memory alloy wires are fabricated through ultrasonic consolidation process which induce a plastic flow between two $\mathrm{Al}$ foils being bonded. The result discussed that this kind of fabrication need cold process for fibre embedding [1]. The Al matrix alloy (A384) reinforced with $\mathrm{SiC}$ of $10 \%$ prepared by stir casting with high stirring time and speed (500, 600 and $700 \mathrm{rpm})$ resulted in even distribution of reinforcement material. The composites formed have better hardness when compared to MMC's formed at low stirring speed and time. By increasing the stirring speed and stirring time of the composite better hardness is achieved. (i.e) stirring speed of $600 \mathrm{rpm}$ and stirring for $10 \mathrm{mins}$ that reaches the maximum Brinell hardness value of about $107 \mathrm{BHN}$ [2]. AMC (Aluminium Matrix Composites) fabricated using stir casting with $\mathrm{SiC}$ (3 to $9 \mathrm{wt} \%)$ and $\mathrm{Cu}(0.5$ to $1.0 \mathrm{wt} \%)$ as reinforcements, under inert atmosphere to neglect the oxidation process that showed fine grain size with increase in reinforcement percentage [3]. Al- $\mathrm{TiB}_{2}$ composites fabricated via exothermic reaction with two different salts such as $\mathrm{K}_{2} \mathrm{TiF}_{6}$ and $\mathrm{KBF}_{4}$ salts used for producing $\mathrm{TiB}_{2}$ particles of various percentage 5,10,15 and $30 \mathrm{wt} \%$. The exothermic reaction improved the wettability of the reinforced particles [4]. Aluminium is reinforced with various percentage of AlN (Aluminium nanoparticles) of $0,2.5,5$ and $10 \mathrm{wt} \%$ were fabricated through high- energy ball milling and sintering technique. The size of the crystal is reduced by sintering for $20-60$ minutes at $650^{\circ} \mathrm{C}$ under Nitrogen gas. This reduces the size of the crystal and improves the reinforcement content where the densification of compact increases through degassed powders [5]. Al- 7093 alloy reinforced with 10 vol\% of $\mathrm{B}_{4} \mathrm{C}$ particles fabricated using Boralyn technique which involves blending, cold isostatic pressing (CIP), vacuum sintering and extrusion process. This cost-effective process provides uniform distribution of reinforcement particles on MMC [6]. 


\section{Property Enhancement of Aluminium Based MMCs with Various Reinforcements}

\section{MECHANICAL PROPERTIES}

Aluminium (A16061) based MMCs prepared by adding various weight percentage of $\mathrm{MoS}_{2}(1 \%, 2 \%, 3 \%, 4 \%, 5 \%)$ using stir casting technique which provides homogenous distribution. It produces better pitting corrosion resistance for 4 wt $\% \mathrm{MoS}_{2}$. AA6061 showed better hardness on heat treatment. The mechanical performance of the composite with $4 \%$ of $\mathrm{MoS}_{2}$ on heat treatment has the highest value while compared with various Weight amounts of $\mathrm{MoS}_{2}$. Thus the heat treated composites showed better properties than others as well as least pit density [7]. Al (99\% purity) based MMCs are prepared by the addition of two different types of abrasives $\mathrm{Al}_{2} \mathrm{O}_{3}$ and $\mathrm{SiC}$ particles separately in various percentage using stir casting and powder metallurgy technique. The result revealed that the specimen prepared by casting exhibits $1.5-2$ times better mechanical and tribological properties than those fabricated by PM techniques [8]. Al6061 with heat treated T6 composites manufactured by modified stir casting with the addition of various weight percentages of $\mathrm{B}_{4} \mathrm{C}$ particles, along with $\mathrm{K}_{2} \mathrm{TiF}_{6}$ flux into the molten matrix to improve wettability. The composite thus prepared has a very good micro and macro hardness value than other techniques and strength (tensile) of Al matrix composites increased to $215 \mathrm{MPa}$. The increase in reinforcement increases the surface area and reduces the grain size. Thus the plastic deformation gets reduced and improves the hardness value of the composite. Thus the addition of reinforcement improves the strength and the thermal mismatch increases the load bearing nature of the composite [9].

\section{A. Micro-structural analysis/porosity}

A356 (Al-7Si-0.35Mg) matrix composite with fly ash particles of $13 \mu \mathrm{m}$ size as reinforcement is fabricated by using three different stir casting technique such as 1) compo casting (semi solid processing), 2) modified compo casting and 3) modified compo casting followed by squeeze casting technique. The result showed that the modified compo casting with surface treatment along with squeeze casting has the best particles than Al356 matrix composite fabricated through liquid metal stir casting (18\%) [10]. AMC prepared by adding micro sized and nano sized $\mathrm{Al}_{2} \mathrm{O}_{3}$ particles using stir casting process followed by a novel 3-step mixing method. This involves heat treatment, injecting the particles which are heat treated into molten alloy under inert gas atmosphere. The stirring process can be carried out at various speeds. The result shows that $\mathrm{Al}-10 \% \mathrm{Al}_{2} \mathrm{O}_{3}(20 \mu \mathrm{m})$ at $300 \mathrm{rpm}$ has a hardness value of 77.1 (HBN) which is the highest value when compared to A356 alloy of hardness 53.1 HBN. Al- 3\% $\mathrm{Al}_{2} \mathrm{O}_{3}(50 \mathrm{~nm})$ at $300 \mathrm{rpm}$ exhibits a hardness value of 76.3 HBN with minimum amount of reinforcement. Before pouring the particle into the melt, the particle is heat treated. This improves the wettability and minimizes the agglomeration. Also, by increasing the stirring speed to the limit of $450 \mathrm{rpm}$, the reinforcement particles distributed evenly and above the speed the alumina particles get wasted and the porosity percentage gets increased [11]. Al alloy (A206) is reinforced with two different reinforcements such as $\mathrm{Al}_{2} \mathrm{O}_{3}$ particles and milled particulates of alumina with $\mathrm{Al}$ and $\mathrm{Mg}$ powders by ball milling followed by stir casting process. Presence of $\mathrm{Mg}$ improves the wettability which leads to the porosity reduction and this property again gets reduced by stirring turbulence. By reducing the size of alumina particles from micro to nano scale dimensions by ball milling the tensile property gets increased. [12]. Light metal matrix composites like Aluminium or Magnesium alloy composites reinforced with MWCNT produced by squeeze casting method whereas the wettability is measured by sessile drop method. With reinforcement of $25 \mathrm{vol} \%, \mathrm{Al}$ or $\mathrm{Mg}$ alloy which obtained is free from porosity [13]. Al 356 alloy matrix composites processed by two ways, stir casting and compocasting with the addition of $5 \%$ of $\mathrm{SiC}$ particle sizes of $8 \mu \mathrm{m}$ and $3 \mu \mathrm{m}$. The compo-casting process improves the distribution of particles and the wettability of the material. The result showed that the porosity reduced to $68 \%$ and the hardness improved by $10 \%$ to $\sim 66 \mathrm{BH}$ because of increase in reinforcement particles [14].

\section{B. Hardness test}

Al6061 based composites fabricated with the reinforcement of $\mathrm{SiC}$ particles of $10 \mathrm{wt} \%$ using Mechanical Alloying (MA) succeeded by mechanical pressing, sintering and hot extrusion. Among them composites processed by MA and hot extrusion have best mechanical properties in its increase in milling time. After 9 hours of milling, the crystal size of $\mathrm{SiC}$ reduced to $36 \mathrm{~nm}$ which is of extreme refined dimensions. As the milling time increases the hardness gets increased, after 9 hours of milling the highest value of hardness $\sim 81 \mathrm{HRB}$ is achieved [15]. Al matrix produced by the reinforcement of 5 and $10 \mathrm{wt} \% \mathrm{Cu}$ powder $(105 \mu \mathrm{m}) \mathrm{using}$ stir casting process showed less wear volume loss as well as high hardness. The COF value is less for $5 \mathrm{wt} \%$ of Al-alloy matrix when compared to $10 \mathrm{wt} \%$ of $\mathrm{Al}$ matrix MMC. Albased $\mathrm{Cu}$ matrix alloy with $5 \mathrm{wt} \% \mathrm{Cu}$ revealed better hardness when compared to other composites [16]. AMC reinforced with Iron-aluminide as well as alumina of 10-50 vol\% fabricated through in-situ exothermic reaction of nano sized $\mathrm{Fe}_{2} \mathrm{O}_{3}$ under mechanical milling followed by hot pressing The greatest hardness of about $\sim 510 \mathrm{VHN}$ is obtained with the reinforcement of $50 \mathrm{vol} \%$ of reinforcement [17]. Aluminum alloy (A356.1) based Metal Matrix Composites are generated through stir casting with the addition of 0.5 to 5 vol\% of $\mathrm{MgO}$ nano particles at different temperatures such as $800^{\circ} \mathrm{C}, 850^{\circ} \mathrm{C}$ and $950^{\circ} \mathrm{C}$. The test results revealed that the MMC has better hardness value of approximately $72 \mathrm{BHN}$ at $2.5 \mathrm{vol} \%$ of reinforcements prepared at temperature of $950^{\circ} \mathrm{C}$. Also the compressive strength of the composite is high for 1.5 volume percentage at $850^{\circ} \mathrm{C}$ of fabrication [18]. Aluminum based MMC prepared by succeeded process like wet mixing, cold pressing and sintering with the reinforcement of nano $\mathrm{Al}_{2} \mathrm{O}_{3}$ particles $(50 \mathrm{~nm})$ of various volume fraction ranging from (1-7 vol\%) in pure ethanol slurry similarly Al composite with 10 vol\% $\operatorname{SiC}_{\mathrm{p}}(13 \mu \mathrm{m})$ was prepared using the same procedure to compare the results. The results revealed that the hardness value lead to decrease after 4 vol\% $\mathrm{Al}_{2} \mathrm{O}_{3}$ (i.e.) 66.6 
HRF (hardness measured in Rockwell indenter) when compared to $7 \mathrm{vol} \% \mathrm{Al}_{2} \mathrm{O}_{3}$ of hardness $68.4 \mathrm{HRF}$. Also, it is evident that 4 vol\% $\mathrm{Al}_{2} \mathrm{O}_{3} / \mathrm{Al}$ composites with a hardness value of 48.6 HRF [19]. There showed a uniform distribution of particle reinforcement under various percentage of graphite particles from 0 to $12 \mathrm{wt} \%$ of Al6082 matrix using stir casting process that decreases in its hardness but the tribological properties tend to increase with increase in reinforcement. The hardness gets reduced from 49.5 VHN (cast Al) to 44 VHN (Al-12\% Gr) [20]. Fabrication of two different MMCs including Aluminium-Cu powder with the reinforcement of $\mathrm{SiC}_{\mathrm{p}}$ and Aluminium- copper powder reinforced with $\mathrm{B}_{4} \mathrm{C}_{\mathrm{p}}$ is fabricated through hot pressing method of $\mathrm{SiC}$ and $\mathrm{B}_{4} \mathrm{C}$ particles of 10,20 and $30 \mathrm{vol} \%$. The result showed that $\mathrm{Al}$ with $30 \mathrm{vol} \%$ of $\mathrm{B}_{4} \mathrm{C}$ composites produce the highest hardness of $190 \mathrm{HB}$ whereas the hardness value for Al-30 vol\% of SiC is approximately $135 \mathrm{HB}$. Also the increase in reinforcement content decreases the wear rate for $\mathrm{Al} / \mathrm{Cu}-\mathrm{SiC}_{\mathrm{p}}$ and $\mathrm{Al} / \mathrm{Cu}-\mathrm{B}_{4} \mathrm{C}_{\mathrm{p}}$ composites [21]. Aluminium alloys AA6061 and AA707 fabricated using liquid casting technique with the reinforcement of $\mathrm{B}_{4} \mathrm{C}(10 \mathrm{wt} \%)$ and graphite $(5 \mathrm{wt} \%)$ and compared among them. The hardness increased due to graphite and $\mathrm{B}_{4} \mathrm{C}$ where $\mathrm{AA} 7075$ hybrid composite showed the highest hardness value of $\sim 120 \mathrm{HB}$. The wear rate shows the lowest for AA7075 hybrid composite which is less than $0.02 \mathrm{mg} / \mathrm{m}$. The tensile property gets improved due to the presence of $\mathrm{B}_{4} \mathrm{C}$ content which enlighten the impregnability of matrix material (AA7075 225 MPa). The reinforcement particles $\mathrm{B}_{4} \mathrm{C}$ and graphite reduces the wear rate which builds the wear resistance of the MMCs [22]. $\mathrm{Al}$ (99.85\%) pure is reinforced with MWCNTs that are created through Spark Plasma Sintering (SPS) along hot extrusion process. These methods provide uniform distribution and orientation of CNT which enables the mechanical characteristics of the composite material. The hardness of Al-CNT increases of about $52 \mathrm{HV}$ than pure $\mathrm{Al}$ which is of about $22 \mathrm{HV}$. The tensile strength of Al-CNT increases twice that of pure Al (194 MPa) [23]. Al6061 alloy fabricated with the various weight percentage of reinforcement particles of $\mathrm{TiO}_{2}(0,4,8,10$ and $12 \mathrm{wt} \%)$ through low and high ball milling technique which gives a very fine nano grain particle. The result revealed as increase in the reinforcement percentage increases the hardness (i.e.) Vickers hardness of Al6061-12\% $\mathrm{TiO}_{2}$ nano composite (1126 $\mathrm{MPa}$ ) increased 3 to 4 times than micro composites (280.48 $\mathrm{MPa}$ ) [24]. Al based MMC (A17075) reinforced with $\mathrm{SiC}$ of 4,8 and 16 vol\% of SiC fabricated using FSP which improve the composite layer bonding. The composite comprised of 4 vol\% of $\mathrm{SiC}$ that has a hardness value ranging from $130 \mathrm{HV}$ to $171 \mathrm{HV}$ on the other hand with 8 vol\% the hardness rate increases from $145 \mathrm{HV}$ to $177 \mathrm{HV}$. However, the relative density percentage of A17075-SiC composite is reduced to $81.5 \%$ (16 vol\% $\mathrm{SiC}$ ) and increased to $87.5 \%$ (4 vol\% $\mathrm{SiC})$ [25].
TABLE - I: Vickers (micro hardness) Hardness value of $\mathrm{Al}$ based MMC with various reinforcements

\begin{tabular}{|c|c|c|c|}
\hline $\begin{array}{l}\text { S. } \\
\text { No }\end{array}$ & MMCs & $\begin{array}{l}\text { Fabrication } \\
\text { Techniques }\end{array}$ & $\begin{array}{l}\text { Hardnes s } \\
\text { (HV) }\end{array}$ \\
\hline 1. & $\mathrm{Al} / \mathrm{SiC}, \mathrm{Cu}$ & Stir casting & 90 \\
\hline 2. & Al6061/AlNp & Modified stir casting & 91 \\
\hline 3. & Al6061/Ti3Alp & Stir casting & 120 \\
\hline 4. & $\begin{array}{l}\mathrm{Al}-\mathrm{Ti}-\mathrm{Cr} / \mathrm{SiC}, \\
\text { B4C }\end{array}$ & $\begin{array}{l}\text { Stir die casting along } \\
\text { with Chillcasting }\end{array}$ & $\begin{array}{l}355.96 \\
(\mathrm{SiC}) \\
217.07 \\
(\mathrm{~B} 4 \mathrm{C})\end{array}$ \\
\hline 5. & Al6061/ MoS2 & Stir casting & 106 \\
\hline 6. & $\begin{array}{l}\mathrm{Al}-\mathrm{Cu} \text { alloy/Cu } \\
\text { powder }\end{array}$ & Stir casting & $\sim 370$ \\
\hline 7. & $\begin{array}{l}\text { A16061-T6/ } \\
\text { B4C }\end{array}$ & Modified stir casting & 80.8 \\
\hline 8. & Al6082/Graphite & Stir casting & 44 \\
\hline 9. & $\mathrm{~A} 359 / \mathrm{SiC}, \mathrm{B} 4 \mathrm{C}$ & Double stir casting & $\begin{array}{l}\sim 159(\mathrm{SiC}) \\
\sim 153 \\
(\mathrm{~B} 4 \mathrm{C})\end{array}$ \\
\hline 10. & A16061/ TiB2 & High energy stir casting & 73.93 \\
\hline 11. & $\begin{array}{c}\text { Al6061/TiB2 } \\
\text { \& Graphite }\end{array}$ & High energy stir casting & 91.4 \\
\hline 12. & $\begin{array}{l}\text { Al6061/Cu } \\
\text { plated carbon } \\
\text { fibre rods }\end{array}$ & Convention al casting & 76.34 \\
\hline 13. & $\mathrm{Al} 6061 / \mathrm{Al} 2 \mathrm{O} 3$ & Stir casting & 180 \\
\hline 14. & Al1100/ B4C & Ball milling \& sintering & 550 \\
\hline 15. & $\mathrm{Al} / \mathrm{AlNp}$ & $\begin{array}{l}\text { High energy ball milling } \\
\text { \& sintering }\end{array}$ & 149 \\
\hline 16. & $\mathrm{Al} / \mathrm{MWCNT}$ & $\begin{array}{l}\text { SPS followed byhot } \\
\text { extrusion }\end{array}$ & 52 \\
\hline 17. & $\mathrm{Al} / \mathrm{MWCNT}$ & $\begin{array}{l}\text { Ball milling \&hot } \\
\text { extrusion }\end{array}$ & $\sim 430$ \\
\hline 18. & $\mathrm{Al} 7075 / \mathrm{SiC}$ & FSP & 177 \\
\hline 19. & $\begin{array}{l}\mathrm{Al} 5059 / \mathrm{SiC}, \mathrm{B} 4 \mathrm{C}, \\
\mathrm{Al}_{2} \mathrm{O} 3\end{array}$ & FSP & 170 \\
\hline 20. & $\mathrm{~A} 16061 / \mathrm{SiC}$ & $\begin{array}{l}\text { Pressure sintering \& hot } \\
\text { extrusion }\end{array}$ & $\sim 160$ \\
\hline 21. & $\mathrm{~A} 15052 / \mathrm{SiC}$ & FSP & 116 \\
\hline 22. & $\mathrm{Al} / \mathrm{Fe}_{2} \mathrm{O}_{3}$ & $\begin{array}{l}\text { Mechanical milling \& } \\
\text { hot pressing }\end{array}$ & $\sim 510$ \\
\hline 23. & $\mathrm{Al6061/ \textrm {TiO } 2}$ & $\begin{array}{l}\text { Low energy \& high } \\
\text { energy ball milling }\end{array}$ & $\sim 350$ \\
\hline 24. & $\mathrm{Al} / \mathrm{Al}_{2} \mathrm{O}_{3}$ & Hot forward extrusion & $\sim 93$ \\
\hline 25. & $\mathrm{Al} / \mathrm{SiC}_{\mathrm{p}}$ & Mechanical alloying & 85 \\
\hline 26. & $\mathrm{Al} / \mathrm{ZrB} 2$ & In situ fabrication & 64 \\
\hline
\end{tabular}

TABLE - II: Brinell hardness (Macro hardness) value of Al based MMC with various reinforcements

\begin{tabular}{|l|l|l|l|}
\hline $\begin{array}{l}\text { S. } \\
\text { No. }\end{array}$ & MMCs & $\begin{array}{l}\text { Fabrication } \\
\text { Techniques }\end{array}$ & $\begin{array}{l}\text { Hardn ess } \\
\text { (BHN) }\end{array}$ \\
\hline 1. & $\begin{array}{l}\text { Al alloys- } \\
\text { ZL109 ZA27/ SiC, } \\
\text { Si3N4, B4C, } \\
\text { A12O3\& graphite } \\
\text { flakes }\end{array}$ & $\begin{array}{l}\text { i)Centrifugal casting } \\
\text { ii)Squeeze casting }\end{array}$ & $\begin{array}{l}\text { 135(ZA 27) } \\
\text { 116(ZL 109) }\end{array}$ \\
\hline 2. & A384/ SiC & Stir casting & 107 \\
\hline 3. & Al6061/ AlNp & Modifiedstir casting & 79 \\
\hline 4. & A356/ Al2O3 & $\begin{array}{l}\text { i)Stir casting ii)Compo } \\
\text { casting }\end{array}$ & 77 \\
\hline
\end{tabular}




\section{Property Enhancement of Aluminium Based MMCs with Various Reinforcements}

\begin{tabular}{|c|c|c|c|}
\hline 5. & $\begin{array}{l}\text { Al6061-T6/ } \\
\text { B4C }\end{array}$ & Modified stir casting & 58.6 \\
\hline 6. & Al/Aloe Vera & Stir casting & 33.8 \\
\hline 7. & $\mathrm{Al}-356-1 / \mathrm{MgO}$ & Stir casting & 72 \\
\hline 8. & $\mathrm{Al} 356 / \mathrm{SiC}$ & $\begin{array}{l}\text { i)Stir casting ii)Compo } \\
\text { casting }\end{array}$ & 66 \\
\hline 9. & $\mathrm{Al} / \mathrm{Al} 2 \mathrm{O} 3 \& \mathrm{SiC}$ & $\begin{array}{l}\text { i) Stir casting ii) } \\
\text { Powder metallurgy }\end{array}$ & $\begin{array}{l}\text { Cast- } 70(\mathrm{Al} 2 \\
\text { O3) } 68(\mathrm{SiC})\end{array}$ \\
\hline 10 . & $\begin{array}{l}\mathrm{A} 17075 / \mathrm{Al}_{2} \mathrm{O} 3 \& \\
\text { Graphite particles }\end{array}$ & Stir casting & $\sim 134$ \\
\hline 11. & $\begin{array}{l}\mathrm{Al} / \mathrm{Al} 2 \mathrm{O} 3 \text { (Micro } \\
\text { \&nano particles) }\end{array}$ & $\begin{array}{l}\text { Three step novel } \\
\text { mixing process } \\
\text { followed by } \\
\text { stir casting }\end{array}$ & 77.1 \\
\hline 12. & $\begin{array}{l}\text { Al6061/ B4C } \\
\text { \& graphite }\end{array}$ & Liquid casting & $\sim 120$ \\
\hline 13. & $\begin{array}{l}\text { Al6061/ Cu plated } \\
\text { carbon fibre rods }\end{array}$ & Conventional casting & 61 \\
\hline 14. & $\begin{array}{l}\mathrm{Al}-\mathrm{Cu} / \mathrm{SiC}_{\mathrm{p}} \& \\
\mathrm{~B} 4 \mathrm{C}\end{array}$ & Hot pressing & $\begin{array}{l}190(\mathrm{~B} 4 \mathrm{C}) \\
135(\mathrm{SiCp})\end{array}$ \\
\hline
\end{tabular}

\section{Strength properties}

A17075 based MMC prepared by stir casting reinforced with $5 \mathrm{wt} \%$ of graphite particles and $\mathrm{Al}_{2} \mathrm{O}_{3}$ particles of $(2,4.6$ and 8 wt. \%). $\mathrm{Al}_{2} \mathrm{O}_{3}$ is added to $\mathrm{Al} 707$ alloy, inorder to improve the hardness which gets reduced by the intervention of graphite particles that retard the hardness rate and by the addition of $\mathrm{Al}_{2} \mathrm{O}_{3}$, the mechanical properties such as hardness, flexural strength, tensile strength and ultimate compressive strength get increased.(refer graph for values) Flexural strength increased $23 \%$ when compared to Al7075. Wear rate gets reduced due to the presence of $\mathrm{Al}_{2} \mathrm{O}_{3}$ upto $36 \%$ less of 2 $\mathrm{wt} \% \mathrm{Al}_{2} \mathrm{O}_{3}$ and $5 \mathrm{wt} \%$ of graphite (minimum wear rate occurs at this stage). Because of graphite content, COF decreases and also the graphite gives a lubricating property [26]. Aluminium 1100 alloy reinforced with various percentage of $\mathrm{B}_{4} \mathrm{C}(0,6$, 10,15 and $25 \mathrm{wt} \%$ ) fabricated using ball milling and sintering. The density and electrical conductivity decrease with increase in $\mathrm{B}_{4} \mathrm{C}$ content. The flexural strength decreases due to the formation of $\mathrm{B}_{4} \mathrm{C}$ derivative on the grain boundaries which can be reduced by heat treatment and brittle nature of MMC. Thus $\mathrm{B}_{4} \mathrm{C}$ is used in nuclear and friction applications [27]. Al- Mg-Si based MMC reinforced with various percentage of $\mathrm{SiC}$ particles $(20,30$ and $40 \mathrm{vol} \%)$ that are fabricated by freeze casting and pressure less infiltration techniques. The compressive strength increases with increases in reinforcement content which shows maximum compressive strength twice that of matrix alloy with $30 \%$ vol $\%$ of SiC along longitudinal direction. The highest value of elastic modulus is $163 \mathrm{GPa}$ with40 vol\% of reinforcement. The result states that with increase in reinforcement percentage of $\mathrm{SiC}$ particles the strong interfacial bonding is occurred [28]. Al based MMC reinforced with $7 \mathrm{wt} \%$ of $\mathrm{SiC}$ particles that are fabricated using compo-casting along with squeeze casting. The result showed that wear resistance, yield strength and compressive strength increases with increase in reinforcement content. The MMC showed higher wear resistance with 20 vol \% of SiC. The compressive strength increased by $45 \%$ than matrix alloy with 15 vol\% [29]. Al based metal matrix composites prepared by stir casting with the reinforcement of fly ash as well as Aloe Vera powder individually to study the mechanical and tribological

properties. The hardness values of AMC-FA and AMC-AV obtained from Brinell hardness number (BHN) are 28.2 and 33.8. The addition of Aloe Vera powder with $\mathrm{Al}$ matrix increases the ultimate tensile strength which proves that AMC-AV is best suitable for high strength applications. Aloe Vera composite provides homogenous distribution and better hardness and tensile strength in its characteristics which is helpful in aerospace, automotive and marine applications [30]. Aluminium alloy (ZL109) matrix composites prepared by the reinforcement of sub-micron $\mathrm{TiB}_{2}$ particles developed by in situ reaction of $\mathrm{K}_{2} \mathrm{TiF}_{6}$ and $\mathrm{KBF}_{4}$ salts, using stir casting with a small addition of $\mathrm{Na}_{3} \mathrm{AlF}_{6}$ as reactive assistant. The results revealed that $8.3 \mathrm{wt} \% \mathrm{TiB}_{2} / \mathrm{ZL} 109$ composite (271 $\mathrm{MPa}$ ) has an increase in UTS value by $105 \mathrm{MPa}$ than ZL109 matrix composite $(166 \mathrm{MPa})$ at $260^{\circ} \mathrm{C}$. when subjected to high temperature, the mechanical properties of composite was evaluated by contribution ratio that characterize the particles effect at varying temperature which improved the peak values for $9.1 \mathrm{TiB}_{2} / \mathrm{ZL} 109$ as $44.6 \%$ and for $8.3 \mathrm{TiB}_{2} / \mathrm{ZL} 109$ as $63.3 \%$ at $260{ }^{\circ} \mathrm{C}$ and above the temperature the contribution gets decreased [31]. Aluminum 6061 composite reinforced with $1 \mathrm{wt} \%$ of graphene fabricated by semi-solid sintering whereas mechanical milling is used for the dispersion of graphene which influence the mechanical properties. By varying the time for ball milling from $10 \mathrm{~min}$ to $90 \mathrm{~min}$, the flexural strength of Al6061-1\% graphene composite gets varied 9 (i.e.) when milling for $60 \mathrm{~min}$, the strength increased to $47 \%$ and for $90 \mathrm{~min}$, the strength increased to $34 \%$ when compared with AL6061. Further milling can help to improve the graphene distribution and degrade the number of stacked layers. This says that the graphene dispersion affects the strength of the composite [32]. Al matrix composite reinforced with nano sized $(35 \mathrm{~nm})$ and submicron $(0.3 \mu \mathrm{m})$ sized alumina particles fabricated by wet attrition milling succeeded by hot forward extrusion process. The result showed that by increasing the amount of nanoparticle, the strength as well as hardness get increased first and then decreased which says that above $4 \mathrm{wt} \%$ of alumina nanoparticles the strength gets reduced [33]. Fabricating Aluminium along $4.5 \mathrm{wt} \%$ of $\mathrm{Cu}$ reinforced with $10 \mathrm{vol} \%$ of $\mathrm{SiC}$ particulate composites through mechanical alloying (MA) technique. $\mathrm{SiC}_{\mathrm{p}}$ increases by increasing the duration of MA and hence the mechanical properties have been improved which exhibits the hardness value of MMC $85 \mathrm{HV}$ whereas MMC without MA is of about $74 \mathrm{HV}$. Mechanically alloyed for 6 hours improved the yield strength from $252 \pm 7 \mathrm{MPa}$ (without MA) to $393 \pm 9 \mathrm{MPa}$ (MA). Likewise, MA for 6 hours increases UTS from $338 \pm 8$ to $463 \pm 8 \mathrm{MPa}$ [34]. Aluminium with $5 \mathrm{wt} \%$ of $\mathrm{Cu}$ reinforced with 13.3 or 27.2 vol\% of $\mathrm{SiC}_{\mathrm{p}}$ $(10 \mu \mathrm{m})$ that are fabricated through conventional hot-pressing method under nitrogen in inert gas atmosphere. The result showed that the yield strength as well as tensile strength is more in $\mathrm{Al}-5 \mathrm{Cu}-30 \% \mathrm{SiC}$ composite $(174 \pm 8 \mathrm{MPa}$ and $241 \pm 9.5 \mathrm{MPa})$. The elongation of $\mathrm{Al}-5 \mathrm{Cu}-30 \% \mathrm{SiC}$ matrix alloy is reduced below $2 \%$ when the reinforcement of 27.2 vol\% of $\mathrm{SiC}$ particles is added which was before above $20 \%$ [35].

Published By: 
Al based MMC fabricated using hot pressing and hot extrusion where pure $\mathrm{Al}$ reinforced with zirconium based glassy particles $\left(\mathrm{Zr}_{57} \mathrm{Ti}_{8} \mathrm{Nb} 2.5 \mathrm{Cu} 13.9 \mathrm{Ni}_{11.1} \mathrm{Al}_{75}\right)$ that are prepared by mechanical alloying. The result discussed that for 40 vol\% glass reinforcement, the compressive strength is 155 $\mathrm{MPa}$ whereas for pure it is $200 \mathrm{MPa}$. For $60 \mathrm{vol} \%$ of glassy reinforcement, the compressive strength increases to 250 $\mathrm{MPa}$ [36].

\section{Yield Strength (MPa)}

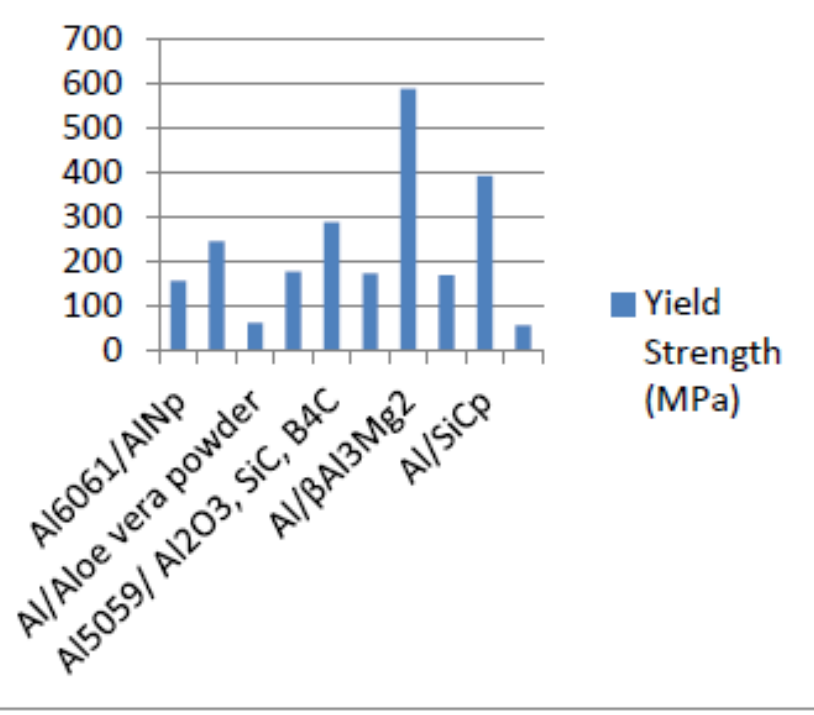

Fig. 1. Yield strength of MMCs with reinforcements

$\mathrm{Al}$ based MMC reinforced with 20 and 40 vol\% of $\beta-\mathrm{Al}_{3} \mathrm{Mg}_{2}$ fabricated using hot extrusion which neglect the unwanted interfacial reaction among matrix and reinforcement. The result exhibited that the density gets reduced to $2.4 \mathrm{~g} / \mathrm{cm}^{3}$ by an increasing amount of reinforcement which is greater than pure $\mathrm{Al}\left(2.7 \mathrm{~g} / \mathrm{cm}^{3}\right)$. For $60 \mathrm{vol} \%$ of $\beta-\mathrm{Al}_{3} \mathrm{Mg}_{2}$, the compressive strength is of about $575 \mathrm{MPa}$ and for $80 \mathrm{vol} \%$ of reinforcement it is increased to $630 \mathrm{MPa}$. Also the specific strength of $20 \mathrm{vol} \%$ of $\beta-\mathrm{Al}_{3} \mathrm{Mg}_{2}$ increases to $180 \mathrm{KNm} / \mathrm{Kg}$ than pure $\mathrm{Al}$ of $55 \mathrm{KNm} / \mathrm{Kg}$. yield strength of $\mathrm{MMC}$ with reinforcement is higher for $80 \mathrm{vol} \%$ reinforcement $(589 \pm 20$ $\mathrm{MPa})$ than $60 \mathrm{vol} \%$ reinforcement $(448 \pm 20 \mathrm{MPa})$ [37]. Aluminium matrix composites manufactured using flake powder metallurgy by adding graphene sheets heighten the tensile strength of $\mathrm{Al}$ composite to $249 \mathrm{MPa}$ with the addition of $0.3 \mathrm{wt} \%$ which is $62 \%$ improvement over aluminium matrix [38]. Al based MMC (A356) fabricated by ball milling followed by a new method called non-contact ultrasonic vibration method with the reinforcement of $\mathrm{SiC}$ nanoparticles that are encapsulated by graphene nanosheets. The result showed that the tensile ductility increased to $84 \%$ and the yield strength increased to $45 \%$ than matrix alloy which also enhances high thermal conductivity. The maximum yield strength of $58 \mathrm{MPa}$ is attained for onion like encapsulating graphene sheets coated MMC [39]. Al5059 reinforced with different reinforcement particles such as $\mathrm{Al}_{2} \mathrm{O}_{3}(130 \mathrm{~nm}), \mathrm{B}_{4} \mathrm{C}$ $(35 \mathrm{~nm})$ and $\mathrm{SiC}(250 \mathrm{~nm})$ that are fabricated by FSP. Due to the reinforcement of $\mathrm{B}_{4} \mathrm{C}$ the hardness value reaches the highest of $170 \mathrm{HV}$ when compared to other reinforcements and the percentage of elongation reduced to $2.5 \%$ for $\mathrm{B}_{4} \mathrm{C}$ content. The yield strength of $\mathrm{Al} 5059-\mathrm{B}_{4} \mathrm{C}$ matrix composite is increased to $290 \mathrm{MPa}$ than $\mathrm{Al} 5059$ (210 MPa). The UTS value of $\mathrm{Al}-\mathrm{Al}_{2} \mathrm{O}_{3}$ increased to $375 \mathrm{MPa}$ and for $\mathrm{B}_{4} \mathrm{C}$ it is 350 $\mathrm{MPa}[40]$.

\section{Ultimate Tensile Strength (MPa)}

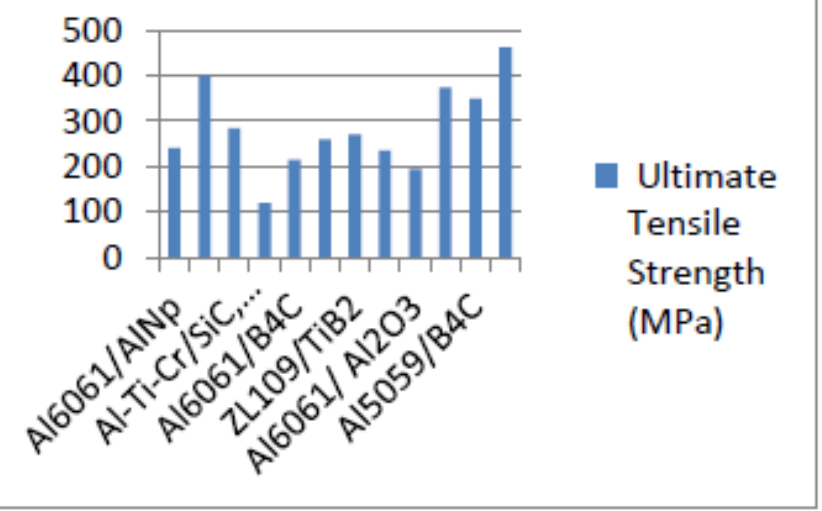

Fig. 2. Ultimate tensile strength of MMCs with reinforcements

\section{Thermal conductivity}

Al matrix composites with diamond powder as reinforcement prepared by two different mixing process such as mechanical mixing (MM) and mechanical alloying (MA) followed by SPS showed a dense, uniform and good thermal conduction properties. By comparing the thermal properties of mechanically mixed and mechanically alloyed composites, the highest thermal conductivity was shown by MM for 2 hours as $325 \mathrm{Wm}^{-1} \mathrm{~K}^{-1}$ whereas the diamond particles gets damaged in MA initially. MM along with SPS provides the composites of high thermal conductivity and increase in relative density [41]. Al based matrix alloy $\left(\mathrm{AlSi}_{7} \mathrm{Mg}_{0.3}\right)$ reinforced with silicon and graphite flakes prepared by pressure infiltration process which are infiltered for $60 \mathrm{~s}$ at the temperature of $760{ }^{\circ} \mathrm{C}$ under $100 \mathrm{MPa}$. Here Si particles are used instead of $\mathrm{SiC}$ because of its low density and to avoid reactivity with $\mathrm{Al}$ melt which $\mathrm{SiC}$ does. Thermal conductivity after reinforcement increased to $526 \mathrm{~W} / \mathrm{mK}$ and the Coefficient of Thermal Expansion reduces to $7.3 \mathrm{ppm} / \mathrm{K}$. This kind of MMC with Graphite flakes is used in low- cost thermal applications [42].

\section{E. Wear test}

Al-6Cu-Mn based MMCs reinforced with 13 vol\% of $\mathrm{SiC}$ particulates by a novel method called spray deposition technique. For sprayed MMC the pores are stable at low loads and as the load increases the porosity level gets high which leads to crack formation and high wear rate [43]. AMC reinforced with various percentage of $\operatorname{TiB}_{2 p}(5,10$ and 15 wt $\%$ ) fabricated through mechanical alloying (2, 4 and 8 hours) followed by cold pressing and pressureless sintering.

Published By:

Blue Eyes Intelligence Engineering \& Sciences Publication 
Hardness rate increases with increase in reinforcement content, with $15 \mathrm{wt} \% \mathrm{TiB}_{2}$ particles for $8 \mathrm{~h}$ of MA showed the microhardness value of $2.43 \pm 0.23 \mathrm{GPa}$ whereas the relative density slightly decreases of about $89.66 \%$.highest wear rate is achieved for $\mathrm{Al}^{-} 5 \mathrm{TiB}_{2}$ is $8.32 \times 10^{-3} \mathrm{~mm}^{3} / \mathrm{Nm}$ and the highest wear resistance is of $7.17\left(\mathrm{Al}-15 \% \mathrm{TiB}_{2}\right)$ [44]. $\mathrm{Al}$ based MMC with SiC particulates are fabricated by Direct Metal Laser Sintering (DMLS) whereas the reinforcement $\mathrm{SiC}$ particles is of different volume percentage (10\%-30\%) that reduces the surface wear and also avoid the plastic formation of material. The specific wear rate is reduced by the addition of reinforcement upto $20 \mathrm{vol} \%$ of $\mathrm{SiC}$ particles and above that there is a very mild decrement of specific wear rate. (At 30 vol\% spec. wear rate is $\sim 0.65 \times 10^{\wedge}-4 \mathrm{~mm}^{3} / \mathrm{Nm}$ ) [45]. A359 alloy (A19Si0.7Mg) MMC fabricated by stir casting method which is of low-cost reinforced with $\mathrm{SiC}(\sim 5$ $\mu \mathrm{m})$ particles with the volume percentage of $20 \%$ for the application of automotive friction materials. From the result the wear rate esteemed of $\mathrm{A} 359-20$ vol\% of $\mathrm{SiC}_{\mathrm{p}}$ gets decreased at the sliding speed range of $3 \mathrm{~m} / \mathrm{s}$ and $6 \mathrm{~m} / \mathrm{s}$ when applying the load from $30 \mathrm{~N}$ to $50 \mathrm{~N}$ and above the load the wear rate gets increased. From the consideration it is clear that when sliding speed increases, the rate wear gets reduced. (At $50 \mathrm{~N}$ the spec. wear rate is $\sim 2 \times 10^{\wedge}-3 \mathrm{~mm}^{3} / \mathrm{m}$ for both sliding speeds). The COF (Coefficient of Friction) ranges of about $0.2-0.65$ at the same sliding speeds. Thus A359-SiC is used as brake rotor applications which provide better wear resistance [46]. Aluminium alloy $\mathrm{A} 359$ with $1 \% \mathrm{Mg}$ is reinforced with $20 \mathrm{vol} \%$ of $\mathrm{SiC}$ and $7.5 \mathrm{vol} \%$ of $\mathrm{B}_{4} \mathrm{C}$ separately fabricated through double stir casting process. The wettability of the composite is improved by double stirring. The result exhibited that the micro hardness value for $\mathrm{Al}-20 \%$ of $\mathrm{SiC}$ is higher than other Particulate reinforced- MMC which is given as for $\mathrm{Al} 7.5 \mathrm{vol} \% \mathrm{~B}_{4} \mathrm{C}\left(155 \mathrm{HV}_{0.5}\right)$ and for $\mathrm{A} 359+1 \% \mathrm{Mg}\left(102 \mathrm{HV}_{0.5}\right)$. The wear rate of $\mathrm{Al}-20 \% \mathrm{SiC}$ is more than $\mathrm{Al} 7.5 \% \mathrm{~B}_{4} \mathrm{C}$ and $\mathrm{A} 359+1 \% \mathrm{Mg}$ alloy due to $\mathrm{SiC}$ particle present in high volume percentage [47]. Aluminium alloy (A16061) reinforced with copper plated carbon fiber rods prepared by conventional casting route. The result exposed that an increase in density of matrix composite by $11 \%$ compared to cast alloy (A16061). The micro hardness and bulk hardness of Al6061 - Cu plated carbon fiber is $76.34 \mathrm{VHN}$ and $61 \mathrm{BHN}$ (25 vol\% of carbon fibers) there is also a reduction in grain size by $36 . \%, \mathrm{COF}$ and wear rate by $14.2 \%$ and $54 \%$ when compared with other. Thus AL6061 reinforced composite showed excellent properties which improve the wear resistance at high velocity that are used in automobile brake drum applications [48].

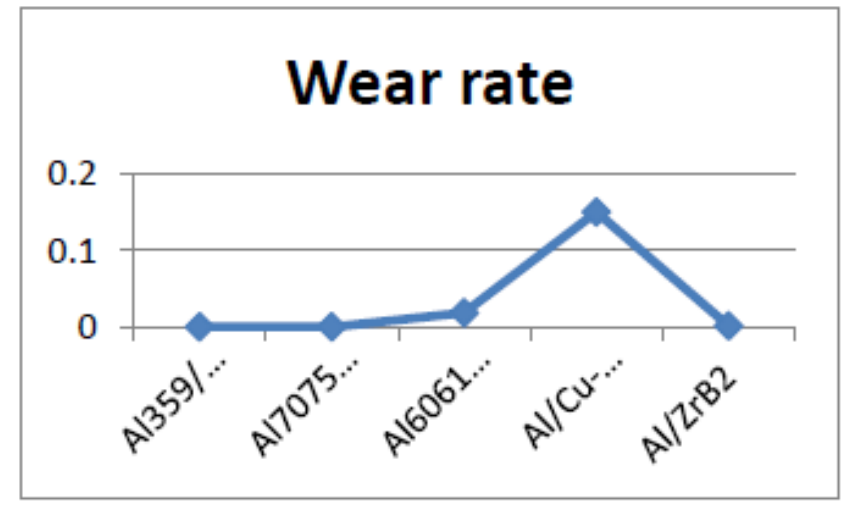

Fig. 3. Wear rate of MMCs with reinforcements

\section{SUMMARY}

This paper represents MMCs with various reinforcements and its properties including tribological and mechanical properties have been reviewed. The Metal Matrix Composites have major properties like excellent hardness, better wear resistance, and high thermal and electrical conductivity, etc. Aluminium matrix composites with hybrid reinforcement showed better isotropic properties than others through powder metallurgy or other casting techniques. The wear rate and the hardness increases by increasing the reinforcement content. Beyond the limit of reinforcement either in weight wise or percentage wise the properties tends to decreases due to high friction rate and agglomeration of particle with increase in reinforcement. The comparisons of MMCs with different reinforcements are made. Aluminium matrix composites are commonly fabricated through stir casting and powder metallurgy but in recent research such fabrication techniques are overcome by Additive manufacturing. This technique has some future scope due to its cost- effectiveness and material saving feature.

\section{REFERENCES}

1. C.Y. Kong, R.C. Soar, "Fabrication of metal-matrix composites and adaptive composites using ultrasonic consolidation process," Materials Science and Engineering vol. 412, 2005, pp.12-18.

2. S. Balasivanandha Prabu, L. Karunamoorthy, S. Kathiresan,B. Mohan, "Influence of stirring speed and stirring time on distribution of particles in cast metal matrix composite," Journal of Materials Processing Technology vol. 171, 2006, pp. 268-273.

3. Ajitanshu Vedrtnam, Anuj Kumar, "Fabrication and wear characterization of silicon carbide and copper reinforced aluminium matrix composite," Materials Discovery, vol 9, 2017, pp. 6-22.

4. S. Lakshmi, L. Lu, M. Gupta, "In situ preparation of TiB2 reinforced Al based composites," Journal of Materials Processing Technology, vol. 73,1998, pp. 160-166.

5. Hamid Abdolia, Hamed Asgharzadeha, Esmail Salahib, "Sintering behavior of Al-AlN-nanostructured composite powder synthesized by high-energy ball milling," Journal of Alloys and Compounds, vol. 473, 2009, pp. 116-122.

6. H.M. Hu, E.J. Lavernia, W.C. Harrigan, J. Kajuch, S.R. Nutt, "Microstructural investigation on B4C: Al-7093 composite," Materials Science and Engineering, vol. 297, 2001, pp. 94-104.

7. E. Subba Rao, N.Ramanaiah, "Influence of Heat Treatment on Mechanical and Corrosion Properties of Aluminium Metal Matrix composites (AA 6061 reinforced with MoS2)," Materials Today: Proceedings, vol. 4, 2017, pp. 11270-11278.

8. Bekir Sadık Unlu, "Investigation of tribological and mechanical properties Al2O3-SiC reinforced $\mathrm{Al}$ composites manufactured by casting or $\mathrm{P} / \mathrm{M}$ 
method," Materials and Design, vol. 29, 2008, pp. 2002-2008.

9. K. Kalaiselvan, N. Murugan, Siva Parameswaran, "Production and characterization of AA6061-B4C stir cast composite," Materials and Design, vol. 32, 2011, pp. 4004-4009.

10. T.P.D. Rajan, R.M. Pillai, B.C. Pai, K.G. Satyanarayana, P.K. Rohatgi, "Fabrication and characterisation of Al-7Si- $0.35 \mathrm{Mg} / \mathrm{fly}$ ash metal matrix composites processed by different stir casting routes," Composites Science and Technology, vol. 67, 2007, pp. 3369-3377.

11. S.A. Sajjadi, H.R. Ezatpour, H. Beygi, "Microstructure and mechanical properties of $\mathrm{Al}-\mathrm{Al} 2 \mathrm{O} 3$ micro and nanocomposites fabricated by stir casting," Materials Science and Engineering A, vol. 528, 2011, pp. 8765-8771.

12. S. Tahamtan, A.Halvaee, M.Emamy, M.S.Zabihi, "Fabrication of Al/A206-A12O3 nano/micro composite by combining ball milling and stir casting technology," Materials and Design, vol. 49, 2013, pp. 347-359.

13. Hisao Uozumi, Kenta Kobayashi, Kota Nakanishi, Tadashi Matsunaga, Kenji Shinozaki, Hiroki Sakamoto, Takayuki Tsukada, Chitoshi Masud, Makoto Yoshida, "Fabrication process of carbon nanotube/light metal matrix composites by squeeze casting," Materials Science and Engineering A, vol. 495, 2008, pp. 282-287.

14. S. Amirkhanlou, B. Niroumand, "Synthesis and characterization of 356-SiCp composites by stir casting and compocasting methods," Trans. Nonferrous Met. Soc. China 20, 2010, pp. 788-793.

15. N. Parvina, R. Assadifard, P. Safarzadeh, S. Sheibani, P. Marashi, "Preparation and mechanical properties of SiC- reinforced Al6061 composite by mechanical alloying," Materials Science and Engineering A, vol. 492, 2008, pp. 134-140.

16. P. Vijaya Kumar Raju, S. Rajesh, J. Babu Rao, N.R.M.R. Bhargava, “ Tribological behavior of $\mathrm{Al}-\mathrm{Cu}$ alloys and innovative $\mathrm{Al}-\mathrm{Cu}$ metal matrix composite fabricated using stir- casting technique," Materials Today: Proceedings, vol. 5, 2018, pp. 885-896.

17. D. Roy, S. Ghosh, A. Basumallick, B. Basu, "Preparation of Fe-aluminide reinforced in situ metal matrix composites by reactive hot pressing," Materials Science and Engineering A, vol. 415, 2006, pp. 202-206.

18. A. Ansary Yar, M. Montazerian, H. Abdizadeh, H.R. Baharvandi, "Microstructure and mechanical properties of aluminum alloy matrix composite reinforced with nano-particle $\mathrm{MgO}$," Journal of Alloys and Compounds, vol. 484, 2009, pp. 400-404.

19. Yung-Chang Kang, Sammy Lap-Ip Chan, "Tensile properties of nanometric $\mathrm{A} 12 \mathrm{O} 3$ particulate-reinforced aluminum matrix composites," Materials Chemistry and Physics, vol. 85, 2004, pp. 438-443.

20. Sharma, Satpal Sharma, Dinesh Khanduja, "A study on microstructure of aluminium matrix composites," Journal of Asian Ceramic Societies, vol. 3, 2015, pp. 240-244.

21. Fevzi Bedir, "Characteristic properties of $\mathrm{Al}-\mathrm{Cu}-\mathrm{SiCp}$ and $\mathrm{Al}-\mathrm{Cu}-\mathrm{B} 4 \mathrm{Cp}$ composites produced by hot pressing method under nitrogen atmosphere," Materials and Design, vol. 28, 2007, pp. $1238-1244$.

22. A. Baradeswaran, S.C. Vettivel, A. Elaya Perumal, N. Selvakumar, R. Franklin Issac, "Experimental investigation on mechanical behaviour, modelling and optimization of wear parameters of B4C and graphite reinforced aluminium hybrid composites," Materials and Design, vol. 63, 2014, pp. 620-632.

23. Hansang Kwon, Mehdi Estili, Kenta Takagi, Takamichi Miyazaki, Akira Kawasaki, "Combination of hot extrusion and spark plasma sintering for producing carbon nanotube reinforced aluminium matrix composites," Carbon, vol. 4 7, 200 9, pp. 5 70-5 77.

24. S. Sivasankaran, K. Sivaprasad, R. Narayanasamy, Vijay Kumar Iyer, "Synthesis, structure and sinterability of 6061 AA100-x-x wt.\% TiO2 composites prepared by high-energy ball milling," Journal of Alloys and Compounds, vol. 491, 2010, pp. 712-721.

25. H. Izadi A., Nolting C., Munro D.P., Bishop K.P., Plucknett A.P., Gerlich, "Friction stir processing of $\mathrm{Al} / \mathrm{SiC}$ composites fabricated by powder metallurgy," Journal of Materials Processing Technology, vol.213, 2013, pp. 1900-1907.

26. A. Baradeswaran, A. Elaya Perumal, "Study on mechanical and wear properties of Al 7075/Al2O3/graphite hybrid composites," Composites: Part B, vol. 56, 2014, pp. 464-471.

27. R.M. Mohanty, K. Balasubramanian, S.K. Seshadri, "Boron carbide-reinforced alumnium 1100 matrix composites: Fabrication and properties,” Materials Science and Engineering A, vol. 498, 2008, pp. $42-52$.

28. Alateng Shaga, Ping Shen, Chang Sun, Qichuan Jiang,
"Lamellar-interpenetrated $\mathrm{Al}-\mathrm{Si}-\mathrm{Mg} / \mathrm{SiC}$ composites fabricated by freeze casting and pressureless infiltration," Materials Science Engineering A, vol. 630, 2015, pp.78-84

29. C. Milliere, M. Suery, "Fabrication and properties of metal matrix composites based on SiC fibre reinforced aluminium alloys," Materials Science and Technology, vol. 4, 1988, 41-51

30. Ch.Hima Gireesh, K.G.Durga Prasad, K.Ramji, P.V.Vinay, "Mechanical characterization of aluminium metal matrix composite reinforced with aloe vera powder," Materials Today: Proceedings, vol. 5, 2018, pp. 3289-3297.

31. Hongzhan Yi, Naiheng Ma, Xianfeng Li, Yijie Zhang, Haowei Wang, “ High-temperature mechanics properties of in situ TiB2p reinforced Al-Si alloy composites," Materials Science and Engineering A, vol 419, 2006, pp. 12-17.

32. Mina Bastwros, Gap-Yong Kim, Can Zhu, Kun Zhang, Shiren Wang, Xiaoduan Tang, Xinwei Wang, "Effect of ball milling on graphene reinforced Al6061 composite fabricated by semi-solid sintering," Composites: Part B, vol. 60, 2014, pp. 111-118.

33. M. Tabandeh Khorshid, S.A. Jenabali Jahromi, M.M. Moshksar, "Mechanical properties of tri-modal Al matrix composites reinforced by nano- and submicron-sized $\mathrm{Al} 2 \mathrm{O} 3$ particulates developed by wet attrition milling and hot extrusion," Materials and Design vol. 31, 2010, pp. 3880-3884.

34. L. Lu, M.O. Lai, C.W. Ng, "Enhanced mechanical properties of an $\mathrm{Al}$ based metal matrix composite prepared using mechanical alloying," Materials Science and Engineering A, vol. 252, 1998, pp. 203-211.

35. B. Ogel, R. Gurbuz, "Microstructural characterization and tensile properties of hot pressed $\mathrm{Al}-\mathrm{SiC}$ composites prepared from pure $\mathrm{Al}$ and $\mathrm{Cu}$ powders," Materials Science and Engineering A, vol. 301, 2001, pp. 213-220.

36. S. Scudino, G. Liu, K.G. Prashanth, B. Bartusch, K.B. Surreddi, B.S Murty, J. Eckert, "Mechanical properties of Al- based metal matrix composites reinforced with $\mathrm{Zr}$-based glassy particles produced by powder metallurgy," Acta Materialia, vol. 57, 2009, pp. 2029-2039.

37. S. Scudino, G. Liu, M. Sakaliyska, K.B. Surreddi, J. Eckert, "Powder metallurgy of Al-based metal matrix composites reinforced with b-Al3Mg2 intermetallic particles: Analysis and modeling of mechanical properties," Acta Materialia, vol. 57, 2009, pp 4529-4538.

38. Jingyue Wang,a Zhiqiang Li, Genlian Fan,a Huanhuan Pan, Zhixin Chen, Di Zhang, "Reinforcement with graphene nanosheets in aluminum matrixcomposites," Scripta Materialia, vol. 66, 2012, pp 594-597.

39. A. Fadavi Boostani, S. Tahamtan, Z.Y. Jiang, D. Wei, S. Yazdani, R. Azari hosroshahi, R. Taherzadeh Mousavian, J. Xu, X. Zhang, D Gong, "Enhanced tensile properties of aluminium matrix composites reinforced with graphene encapsulated SiC nanoparticles,' Composites: Part A, vol. 4, 2014, pp.41-51

40. S. Sahraeinejad, H. Izadi, M. Haghshenas, A.P.Gerlich, "Fabrication of metal matrix composites by friction stir processing with different Particles and processing parameters," Materials

$$
\text { \& } \quad \text { Engineering A, vol.. 626,pp. 507-513. }
$$

41. Chu Ke, Jia Chengchang, Liang Xuebing, Chen Hui, "Effect of powder mixing process on the microstructure and thermal conductivity of $\mathrm{Al}$ /diamond composites fabricated by spark plasma sintering,"Rare Metals Vol. 29, 2010, pp. 86-91.

42. Cong Zhou, Gang Ji, Zhe Chen, Mingliang Wang, Ahmed Addad, Dominique Schryvers,Haowei Wang, "Fabrication, interface characterization and modeling of oriented graphite flakes/Si/A composites for thermal management applications," Materials and Design, vol. 63, 2014, pp. 719-728.

43. Manchang Gui, Suk Bong Kang, Jung Moo Lee, "Influence of porosity on dry sliding wear behavior in spray deposited $\mathrm{Al}-6 \mathrm{Cu}-\mathrm{Mn}: \mathrm{SiCp}$ composite," Materials Science and Engineering A, vol. 293, 2000, pp 146-156.

44. Ozge Balc, Duygu Ag aog ulları, Hasan Gokce, Ismail Duman, M Lutfi Ovecog $`$ lu, "Influence of TiB2 particle size on the microstructure and properties of $\mathrm{Al}$ matrix composites prepared via mechanical alloying and pressureless Sintering," Journal of Alloys and Compounds, vol. 586, 2013, pp.78-84. 
45. Subrata Kumar Ghosh, Partha Saha, "Crack and wear behavior of SiC particulate reinforced aluminium based metal matrix composite fabricated by direct metal laser sintering process," Materials and Design, vol. 32, 2011, pp. 139-145.

46. A. Daoud, M.T.AbouEl-khair, "Wear and friction behavior of sand cast brake rotor made of A359-20 vol\% SiC particle composites sliding against automobile friction material," Tribology International, vol. 43, 2010, pp. 544-553.

47. Barbara Previtali, Dante Pocci, Cataldo Taccardo, "Application of traditional investment casting process to aluminium matrix composites," Composites: Part A, vol. 39, 2008, pp. 1606-1617.

48. C.S. Ramesh, H. Adarsha, S. Pramod, Zulfiqar Khan, "Tribological characteristics of innovative Al6061-carbon fiber rod metal matrix composites," Materials and Design, vol. 50, 2013, pp. 597-605.

\section{AUTHORS PROFILE}

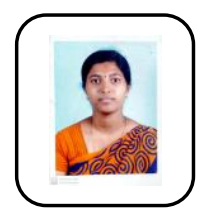

Mrs. J. R. Jessy Michla obtained her Bachelor's degree in Aeronautical Engineering from Vel Tech Engineering College, Chennai with the university rank - 15 and Master's degree in Computer Aided Design from Government College of Engineering, Salem with a top rank score. Currently, she was pursuing her $\mathrm{PhD}$ in Mechanical Engineering, Kalasalingam Academy of Research and Education.

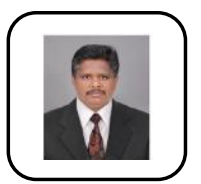

Dr. N. Rajini obtained his Bachelor's degree in Mechanical Engineering from Manonmaniam Sundaranar University, Tirunelveli in 1999. He was awarded his Master's degree in Engineering Design from Anna University, Chennai in 2004. Then he was awarded his PhD in Composite Materials from Kalasalingam University, Krishnankoil in 2013.He completed his post-doctoral fellowship in Ghent University, Belgium in 2015. Visiting Scientist at INTROP, University Putra Malaysia, Malaysia and KMUTNB, Bangkok. He is a member of ISTE. He brings to his position in a well-balanced background in polymers. He has published more than 70 international journals also published more than 30 papers in International Conference proceedings. He was a Co-Principal Investigator for a funded project of Tamilnadu State Council for Science and Technology. Currently he is working as Professor in Mechanical Engineering Department, Kalasalingam Academy of Research and Education since 2004. 